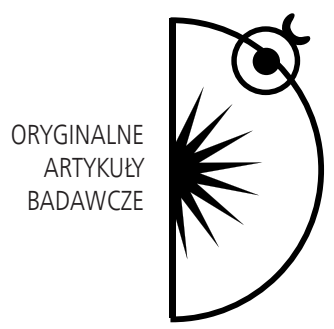

Walentyna Wróblewska

\title{
Postawy studentów wobec działalności w kołach naukowych
}

DOI: http://dx.doi.org/10.12775/PBE.2013.016

\section{Wprowadzenie}

W ostatnich latach szkolnictwo wyższe przeżywa ogromne zmiany, które w szczególności są związane z realizacją procesu bolońskiego. Przez wieki podstawową funkcją uniwersytetu (mam tu na myśli całe szkolnictwo wyższe) było przede wszystkim tworzenie i przekazywanie wiedzy. Zgodnie z koncepcją Deklaracji Bolońskiej „,funkcję tę należy rozszerzyć o wspieranie studentów, nie tylko w procesie kształcenia, ale także i nabywania przez nich kompetencji" (Furmańska, 2010, s. 36). Obecnie przeżywamy wdrażanie do rzeczywistości akademickiej Krajowych Ram Kwalifikacji, według których efekty kształcenia akademickiego koncentrują się wokół trzech kategorii: wiedzy, umiejętności i kompetencji społecznych. Ponadto zakłada się kumulowanie osiągnięć studenta, zdobytych w ramach edukacji formalnej i nieformalnej, pozaformalnej. Ważność zajęć pozaprogramowych wynika ze zmian przyznawania stypendiów naukowych studentom. Do tej pory głównym kryterium przyznawania tego typu pomocy/nagrody materialnej studentom była średnia ocen uzyskana w toku studiów za ostatni rok akademicki. Obecnie obok średniej ocen, uwzględnia się aktywność naukową, społeczną, artystyczną, sportową itp. 
W prezentowanym opracowaniu chciałabym zwrócić uwagę na jeden z rodzajów aktywności pozaprogramowej studentów, jakim jest działalność w kołach naukowych. Przedstawiam postawy studentów wobec działalności w kołach naukowych na podstawie wybranych losowo opinii badanych. W grupie badanej byli studenci zaangażowani i niezaangażowani w tego rodzaju działalność naukową.

\section{Niektóre ustalenia terminologiczne i metodologiczne}

Podejmując trud rozpoznania działalności naukowej studentów, zdecydowałam się na analizę postaw wobec tego rodzaju aktywności studentów. Termin ,,postawa” jest definiowany przez przedstawicieli różnych dyscyplin naukowych, a przede wszystkim przez filozofów, psychologów, socjologów, i rozmaicie rozumiany. Na podstawie różnych definicji można przyjąć, iż postawa jest określonym stosunkiem do pewnej rzeczy, obiektu, procesu, fragmentu rzeczywistości, obejmującym przynajmniej trzy komponenty: poznawczy, emocjonalny i behawioralny. Takie ujęcie postawy jest charakterystyczne dla poznawczej koncepcji postawy (Miki, za: Soborski, 1987, s. 14-15), które stanowi fundament dla mojego myślenia o postawie i jej analizowania.

Element poznawczy określa zasób informacji, wiedzę i przekonania wobec przedmiotu postawy. Posiadana wiedza może być opisywana ze względu na jej rozległość i prawdziwość. Stopień rozbudowania komponentu można uporządkować: od postaw, w których komponent poznawczy jest zaledwie zarysowany, sprowadzony do przekonania o istnieniu lub możliwości istnienia pewnego przedmiotu, do postaw, gdzie wiedza o własnościach i funkcjach przedmiotu jest rozległa. Uważam, że trzeba tu zwrócić uwagę na pojęcie przekonań, które oznaczają w tym ujęciu intelektualny stan pewności o realności lub słuszności jakiegoś przedmiotu lub stanu rzeczy. Powstają one w procesie internalizacji wiedzy i stają się podstawą określenia własnych ocen.

Komponent afektywny ukazuje postawę jako uczucia przejawiane w stosunku do przedmiotu postawy, które mają określony kierunek oraz siłę. Może być wyrażany w postaci dodatnich lub ujemnych emocji, ocen związanych z przedmiotem postawy, które przybierając werbalną formę, są uzewnętrzniane słowami, takimi jak dobry, zły, słuszny, niesłuszny. Siła emocji wskazuje na intensywność postawy, pozwala na uporządkowanie ich w sposób jednowymiarowy (od wartości dodatnich, przez obojętne, do silnie ujemnych). Komponent ten nadaje kierunek postawie, tzn. określa pozytywny lub negatywny stosunek do danego przedmiotu. 
Behawioralny składnik danej koncepcji opisuje zachowania intencjonalne bądź realne wobec przedmiotu postawy, mniej lub bardziej jednorodny zespół zachowań wobec obiektu postawy. W ludzkiej psychice istnieje skrystalizowany program postępowania w stosunku do przedmiotu postawy. Program ten może być bezpośrednio i subiektywnie postrzegany przez posiadacza postawy jako intencje, pragnienie, roszczenie czy poczucie powinności zachowania się w określony sposób. Za pośrednictwem tego składnika realizują się praktyczne zamierzenia człowieka, powstaje działanie o charakterze i kierunku wyznaczonym przez dwa pozostałe układy elementarne postawy: poznawczy i emocjonalny. Program działania może być w postawach wyraźnie określony lub też tylko zaznaczony, ograniczony do pewnych wskazań, jak zachować się wobec obiektu postawy.

Niektóre postawy mogą być bardziej zdeterminowane emocjonalnie, inne natomiast poznawczo. Zróżnicowany rozkład poszczególnych komponentów postawy może warunkować to, że w odniesieniu do niektórych postaw lub ludzi komponenty afektywne lepiej objaśniają ogólne postawy, natomiast w innych przypadkach lepsze są w tym celu komponenty poznawcze.

Głównym celem badawczym było rozpoznanie postaw studentów wobec działalności w kołach naukowych. Wynika $\mathrm{z}$ tego następujący problem badawczy: jakie postawy reprezentują studenci wobec działalności w kołach naukowych? Z przyjętej definicji postawy wynikają szczegółowe problemy badawcze:

1. Jaką wiedzę posiadają badani na temat funkcjonujących kół naukowych?

2. Jaki stosunek emocjonalny przejawiają respondenci wobec tego typu działalności naukowej?

3. Jak przejawia się zaangażowanie studentów w działalność kół naukowych?

Do rozpoznania postaw studentów wobec działalności w kołach naukowych przeprowadzono badania za pomocą metody sondażu diagnostycznego, techniki ankiety i autorskiego kwestionariusza wśród studentów II i V roku studiów stacjonarnych Wydziału Pedagogiki i Psychologii Uniwersytetu w Białymstoku. Łącznie przebadano 211 respondentów obu roczników, czyli 87 studentów II roku oraz 124 studentów V roku, co stanowiło ogółem 35\% populacji.

\section{Komponenty postaw studentów wobec działalności w kołach naukowych}

W badaniach nad postawami studentów wobec działalności w kołach naukowych, zgodnie z przyjętą koncepcją, wyróżniono trzy komponenty postawy. 
Pierwszy komponent poznawczy obejmował wiedzę studentów na temat rodzajów i działalności kół naukowych oraz wiedzę o przebiegu rekrutacji do kół naukowych. Do komponentu emocjonalnego zaliczono: określenie przydatności, ocenę działalności kół przez studentów oraz poparcie bądź jego brak dla tej działalności. Trzeci komponent behawioralny dotyczył rzeczywistej aktywności w kołach naukowych (okresu przynależności i działalności w kole).

\section{Komponent poznawczy}

Na komponent poznawczy postaw składała się wiedza studentów na temat rodzajów i działalności kół naukowych oraz wiedza o przebiegu rekrutacji. $\mathrm{Na}$ Wydziale Pedagogiki i Psychologii Uniwersytetu w Białymstoku, na którym przeprowadzono badania, działa aktualnie bądź działało w ostatnich pięciu latach 16 studenckich kół naukowych: Edukacji Międzykulturowej, Historii Wychowania, Młodych Wolontariuszy, Pedagogiki Specjalnej, Filmoznawstwa, Młodych Teoretyków Pedagogiki, Aktywnych Dydaktyków, Psychologii, Kreatywności, Socjologii Edukacji, Filozoficzne, Andragogów i Gerontologów, Pedagogiki Resocjalizacji, Galeria „Stotrzynaście”, Artystyczne Koło Teatralne, Etnoedukacji.

Na pytanie, ,Jakie zna Pan/Pani koła naukowe na wydziale?”, 10 studentów $(4,7 \%)$ nie wymieniło żadnego koła, pozostali respondenci $(95,3 \%)$ potrafili wymienić przynajmniej jedno działające na wydziale koło naukowe. Należy zwrócić uwagę, iż studenci w swoich odpowiedziach zmieniali nazwy kół bądź wymieniali koła, które nie istnieją na ich wydziale. Można przypuszczać, że w odpowiedziach ujawniły się oczekiwania studentów, aby owe koła powstały. Wymieniane były tu dwie nazwy: koło krajoznawcze oraz koło pedagogiki społecznej. $\mathrm{Z}$ badań wynika, że najczęściej wymienianymi, a co za tym idzie, jak można przypuszczać, najbardziej znanymi kołami są: Koło Filozoficzne oraz Koło Młodych Wolontariuszy. Były one wymieniane przez ponad 40\% respondentów. Studenci w kwestionariuszach ankiet nie wymienili dwóch istniejących kół: Galerii Stotrzynaście oraz Koła Etnoedukacji. 
Wykres 1. Koła naukowe wymieniane przez respondentów



Źródło: badania własne.

Analiza wiedzy studentów na temat sposobu naboru do kół naukowych pokazuje, iż 138 respondentów, co stanowi 65,40\% wszystkich badanych oświadczyło, iż nie wie, jak przebiega rekrutacja do kół naukowych. Wśród osób wykazujących się wiedzą na ten temat do najczęściej podawanych rozwiązań naboru można zaliczyć:

- każdy chętny może się zgłosić - 43,83\%,

- należy przyjść na spotkanie organizacyjne - 38,36\%,

- należy zgłosić się do przewodniczącego wybranego koła - 15,07\%.

Badany komponent poznawczy postawy można określić jako ledwie zarysowany, sprowadzony do przekonania o istnieniu przedmiotu postawy. 


\section{Komponent emocjonalny}

Na postawy studentów składa się również element emocjonalny, który analizowano przez określenie potrzeby istnienia kól, oceny i poparcia dla ich działalności.

Według odpowiedzi studentów na pytanie, „Czy uważa Pan/Pani koła naukowe za potrzebne na uczelniach wyższych?", żadna z badanych osób nie uznała, aby koła naukowe były niepotrzebne. Około $1 / 5$ studentów odpowiedziała, iż jest to dla niej obojętne, natomiast prawie $80 \%$ ankietowanych określiło studenckie koła naukowe jako potrzebne w szkołach wyższych.

Kolejnym wskaźnikiem komponentu afektywnego postaw studentów wobec działalności w kołach naukowych była ocena działalności kół naukowych na ich wydziale. Najczęściej określana była ona jako średnia (ponad 50\% studentów) i dobra (około 32\% studentów), najmniej studentów oceniło ją jako bardzo słabą ( $0,5 \%$ respondentów). W uzasadnieniach oceny średniej studenci najczęściej podawali, że koła mało się reklamują (ok. $47 \%$ ankietowanych) oraz rzadko organizują akcje na wydziale (ok. 40\% osób badanych). Jednocześnie około $13 \%$ respondentów oceniających działalność kół jako średnią zauważyło, że koła jednak organizują różne akcje. Około $2 \%$ respondentów zaznaczyło, iż na wydziale jest duży wybór kół i są o nich jasne informacje dostępne studentom, jednak nie było to dla nich równoznaczne z lepszą działalnością. Prawie 3\% badanych podkreśliło, że tak naprawdę nie ma wiedzy na temat działalności kół naukowych, dlatego trudno im ją opiniować, w związku z tym oceniali ją jako średnią.

Zdecydowana większość badanych studentów (ponad 60\%) oświadczyła, iż popiera działalność kół naukowych na ich wydziale. Dla 1/3 jest ona obojętna, natomiast $1 \%$ badanych nie popiera ich działalności. Studenci, w uzasadnieniu swego poparcia lub jego braku dla działalności studenckich kół naukowych, wymieniali następujące określenia:

- „dzięki działalności w kołach naukowych studenci mogą pogłębiać własne zainteresowania",

- „dzięki działalności w kołach naukowych studenci mogą rozwijać się (mówiąc ogólnie)",

- „dzięki działaniu w kołach naukowych studenci mogą pogłębiać swoją wiedzę",

- „studenci w kołach naukowych organizują różnego rodzaju akcje na wydziale",

- „działający w kołach studenci udzielają pomocy innym ludziom”, 
- „działalność w kołach naukowych jest dobrą formą spędzania wolnego czasu",

- „dzięki działalności w kołach naukowych studenci mogą zdobywać nowe doświadczenia",

- „poprzez działalność w kołach naukowych studenci mogą poznać nowych ludzi",

- „działalność kół naukowych jest pewnego rodzaju wsparciem działalności wydziału",

- „studentów nie interesuje działalność studenckich kół naukowych na ich wydziale".

Trzeba podkreślić, iż około $36 \%$ badanych nie podało tu żadnego uzasadnienia, a około $2 \%$ nie interesuje się w ogóle działalnością kół naukowych. Wśród pozostałych, do najczęściej wymienianych uzasadnień swego poparcia dla kół naukowych należy fakt, iż dzięki działalności w kole naukowym członkowie mogą się rozwijać (ponad 31\% studentów) oraz pogłębiać swoje zainteresowania (ponad 30\% badanych). Ponadto około 17\% studentów upatruje w działalności kół naukowych możliwość pogłębiania własnej wiedzy oraz organizowania różnych akcji. Około 7\% respondentów uznało ową działalność za pewien sposób spędzania czasu wolnego. Najmniej badanych (około 6\%) widzi w działalności studentów w kołach możliwość wsparcia wydziału oraz poznania nowych ludzi. Uzyskane wyniki mogą świadczyć o tym, iż studenci upatrują w działalności w kołach naukowych możliwość autoedukacji i samorozwoju. Mniej istotne w działaniach studentów w kołach naukowych są, według badanych, praca $z$ innymi i na rzecz innych oraz wsparcie wydziału.

Wśród respondentów, którzy nie popierają działalności kół naukowych, dwie osoby uważają, że tego typu działalność jest pewnym wsparciem dla wydziału oraz sposobem na pogłębienie własnej wiedzy. Pozostali badani (83\%) nie udzielili w ogóle wyjaśnienia swego wyboru bądź zaznaczyli, iż nie interesuje ich działalność kół naukowych na wydziale (14\% respondentów).

Analiza komponentu afektywnego pozwala określić pozytywny stosunek badanych do przedmiotu postawy.

\section{Komponent behawioralny}

W przypadku komponentu behawioralnego zwrócono uwagę na przynależność studentów do kół naukowych. Wśród badanych studentów około $80 \%$ nie należy ani nie należało w okresie studiowania do żadnych kół naukowych. Jedna piąta respondentów zadeklarowała swoją działalność w tej organizacji studenc- 
kiej. Chciałabym tu w szczególności podkreślić, iż wśród studentów należących do kół naukowych zaledwie sześć osób z 44 to studenci II roku studiów, pozostałe osoby są studentami $\mathrm{V}$ roku.

Wśród studentów, którzy nigdy nie byli członkami koła naukowego, prawie $50 \%$ planowało kiedyś wstąpienie do studenckiego koła naukowego. Co trzecia osoba badana nigdy o tym nie myślała, natomiast co piąty student nie chciał nigdy wstąpić do organizacji studenckiej, jaką jest koło naukowe. Pomimo że ponad $60 \%$ respondentów podało, iż nie wie, w jaki sposób przebiega rekrutacja do kół naukowych, była to najrzadziej (około 5\% studentów) podawana przyczyna braku ich przynależności do kół naukowych. Do głównych przyczyn niepodejmowania działalności w kołach naukowych przez studentów można zaliczyć brak atrakcyjnych ofert ze strony studenckich kół naukowych - taką odpowiedź wskazała ponad $1 / 4$ ankietowanych.

Studenci zapytani o to, czy jest coś, co zmotywowałoby ich do bycia członkiem koła naukowego, najczęściej odpowiadali, że nic takiego nie istnieje (ponad $40 \%$ respondentów). Około $20 \%$ badanych zadeklarowało, że jedynie atrakcyjny program koła mógłby zmotywować ich do podjęcia działalności. Nieco ponad $12 \%$ badanych określiło, że ewentualna przynależność do koła naukowego byłaby możliwa, gdyby mieli więcej czasu wolnego.

Podsumowując wyniki badań w zakresie analizy poszczególnych komponentów postawy studentów wobec działalności w kołach naukowych, można zauważyć, iż większość studentów posiada wiedzę na temat kół naukowych oraz popiera ich działalność na uczelniach wyższych. Analiza komponentu behawioralnego prowadzi do wniosku, iż $20 \%$ badanych jest zaangażowanych w działalność kół naukowych - w moim odczuciu jest to dość duży odsetek ankietowanych. Analizując główne komponenty postaw studentów wobec aktywności naukowej, zwrócono uwagę na przyczyny niepodejmowania działalności w kołach naukowych przez badanych, wśród których dominowała przyczyna brak atrakcyjnych ofert działań. W badaniach podkreślono również czynniki, które mogłyby zmotywować studentów do podjęcia działalności w tego typu organizacjach. Respondenci wymieniali przede wszystkim atrakcyjny program oraz większy zasób czasu wolnego.

\section{Studenci aktywnie uczestniczący w kołach naukowych}

Powyżej przedstawiono postawy badanych studentów (wybranych losowo) wobec działalności w kołach naukowych. W tym miejscu zostanie zaprezentowana rzeczywista aktywność studentów w kołach naukowych, eksponująca okres 
działalności, ocenę zaangażowania w działalność naukową, przyczyny wstąpienia do koła oraz korzyści, które studenci czerpią z aktywności.

Wykres 2. Okres działalności studentów w kołach naukowych

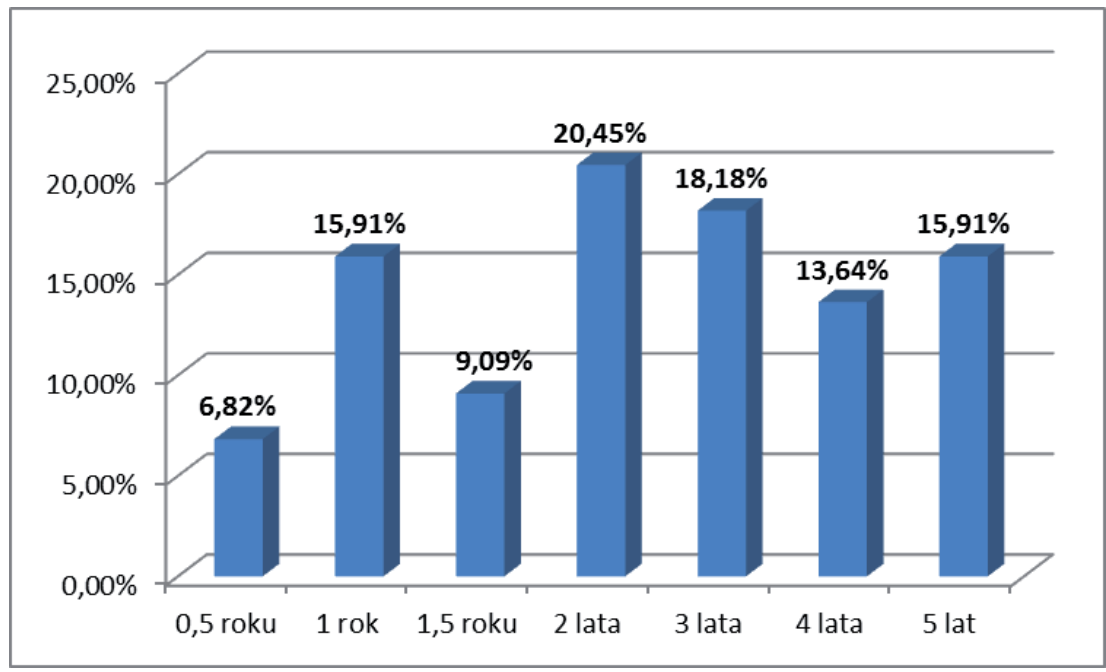

Źródło: badania własne.

Badania pokazują, iż studenci średnio działali w kole przez około 2,5 roku. Trzech respondentów swoją działalność zakończyło po pół roku, co stanowiło około 7\% studentów działających w kole naukowym. Jako powód szybkiej rezygnacji z działalności w kole podawali przede wszystkim brak czasu oraz zawód z powodu mało atrakcyjnego programu koła. Około 10\% ankietowanych było członkami koła naukowego przez 1,5 roku. Okres 4 lat aktywnego działania w studenckim kole naukowym podało 6 respondentów, co stanowi około $14 \%$ badanych. Niecałe $16 \%$ ankietowanych działało w kole rok i 5 lat. Trzy lata studiów na działalność w kole poświęciło 8 studentów (ok. 18\% badanych), był to drugi co do liczby wynik. Najwięcej studentów (bo około 1/5) była zaangażowana przez 2 lata w działalność koła naukowego.

W kwestionariuszu ankiety poproszono studentów, aby dokonali oceny działalności w kole naukowym. Prawie co drugi respondent określił swoją działalność w kole naukowym jako dobrą. W stopniu średnim według badanych działa w kołach naukowych $1 / 3$ studentów. Swoją działalność w organizacji studenckiej jako bardzo dobrą określiło 16\% badanych. Najmniejszy odsetek (bo kolejno $4 \%$ i 2\% studentów) swoją działalność ocenia słabo i bardzo słabo. 
Wykres 3. Ocena działalności kół naukowych przez wszystkich badanych i studentów zaangażowanych w działalność kół

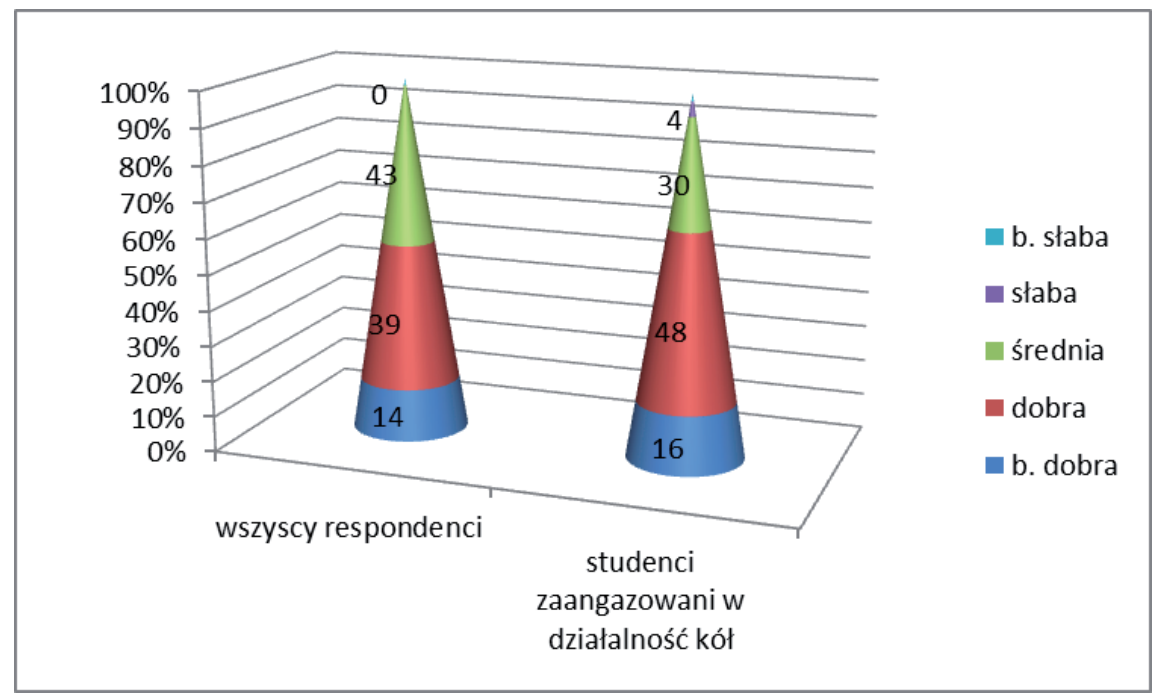

Źródło: badania własne.

W zakresie komponentu emocjonalnego analizowano ocenę działalności kół naukowych deklarowaną przez wszystkich badanych. Zestawiając tę ocenę z oceną studentów zaangażowanych w działalność naukową w kole (wykres 3), można zauważyć, iż bardzo dobra ocena jest zbliżona (14\% i 16\%) w obu grupach studentów. Przy ocenie dobrej przeważa grupa studentów zaangażowanych w działalność kół. Można zauważyć prawidłowość, iż przy wyższych ocenach dominują grupy studentów aktywnie uczestniczących w kołach naukowych. Ocenę średnią przypisało więcej osób niezaangażowanych w działalność naukową. Zaskakujące jest, iż ocena słaba wystąpiła w grupie osób aktywnie działających w kołach.

Ważnym aspektem przy charakterystyce studentów zaangażowanych w działalność w kołach naukowych są motywy wstąpienia i aktywności. Najwięcej ankietowanych, bo 70\% studentów wskazywało, iż wstąpiło do koła naukowego z powodu możliwości rozwijania i zdobywania nowych kompetencji. Prawie $60 \%$ badanych zrobiło to ze względu na chęć samorealizacji. Co drugi student swoją decyzję opierał na zgodności działalności koła z zainteresowaniami osobistymi. Po 40\% studentów zaznaczyło, iż do tego, aby być członkiem koła, skłoniły ich: chęć zdobycia dokumentu do suplementu dyplomu oraz poznanie 
nowych osób. Co trzecia osoba chciała przez działalność w kole naukowym urozmaicić sobie czas wolny. Dwóch respondentów wpisało dodatkowo, że do podjęcia działalności w kole naukowym zmotywowała ich chęć pomocy innym oraz możliwość zwolnienia z egzaminu z przedmiotu, z którym jest związane koło. Wyniki przekonują, że studenci przejawiają swoją aktywność przede wszystkim ze względu na możliwości autoedukacji i samorozwoju, a w mniejszym stopniu decydują motywy związane z relacjami interpersonalnymi.

Istotne jest rozpoznanie, czy decyzja o wstąpieniu do koła miała charakter autonomiczny, czy też osoby z najbliższego środowiska badanych zachęciły ich do wstąpienia do koła naukowego. Żadnego studenta do wstąpienia do koła naukowego nie zachęcili rodzice. Tylko jeden badany podkreślił, iż osobą z rodziny, która miała wpływ na podjęcie jego decyzji o wstąpieniu do koła, była siostra. Ponad 50\% badanych określiło, że decyzja o podjęciu działalności w kole naukowym zależała od nich samych. W drugiej kolejności osobą zachęcającą do aktywności w organizacji studenckiej był(-a) kolega/koleżanka (niecałe 50\% badanych). Osobą, która zachęciła do uczestniczenia w działalności koła co czwartego studenta, był inny członek danego koła naukowego. Prawie co piątego respondenta do przyjęcia roli członka koła zachęcił nauczyciel akademicki.

Interesujące jest również rozpoznanie, co skłania studentów do pozostania w kole naukowym na dłuższy okres czasu czy też jakie korzyści badani czerpią z bycia członkiem koła. Najczęściej respondenci wskazywali na zdobywanie i rozwijanie nowych kompetencji ( $3 / 4$ badanych). Następnie na jednym poziomie uplasowały się takie korzyści, jak: możliwość samorealizacji, zawieranie nowych znajomości oraz rozwijanie własnych zainteresowań $(61 \%$ studentów). Najmniej studentów, bo niewiele ponad połowa, za korzyść z działalności w kole naukowym uznała zdobycie dokumentu do suplementu dyplomu.

\section{Postawy studentów wobec działalności w kołach naukowych}

Na podstawie szczegółowej analizy trzech komponentów postaw studentów wobec działalności w kołach naukowych można wyznaczyć kilka typów postaw. W literaturze przedmiotu spotykamy się z wieloma typologiami postaw. $\mathrm{W}$ prezentowanych badaniach podjęto próbę wyróżnienia postaw ze względu na ich znak: pozytywne (znak dodatni), negatywne (znak ujemny) i neutralne (znak zerowy). Niekiedy do tej klasyfikacji zalicza się również postawę ambiwalentną, w której przypadku występują jednocześnie emocje o różnych znakach (Pilch, 2005, s. 744). 
Wykres 4. Postawy studentów wobec działalności w kołach naukowych

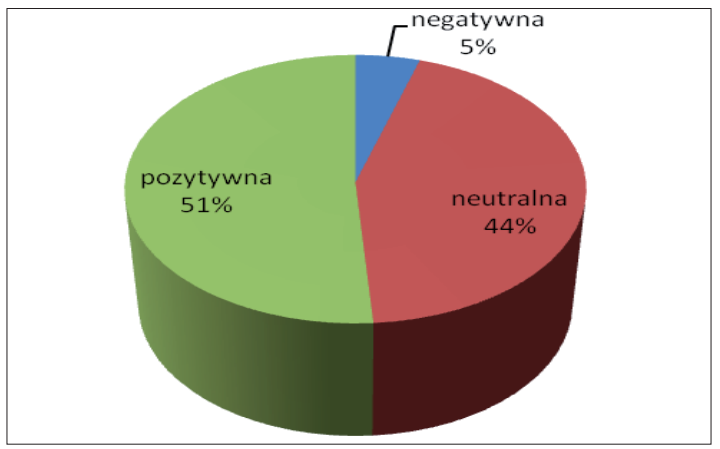

Źródło: badania własne.

Po wnikliwej analizie stosunku każdego respondenta wobec działalności w kołach naukowych zakwalifikowano studentów do poszczególnych typów. $\mathrm{Z}$ badań wynika, że ponad połowa badanych przejawia wobec działalności w kołach naukowych postawę pozytywną. Postawę neutralną przyjmuje 44\% ankietowanych. Studenci przejawiający postawę negatywną stanowią 5\% badanej grupy.

\section{Podsumowanie}

Analiza postaw studentów wobec działalności w kołach naukowych pozwala zauważyć, iż badani dzielą się na dwie grupy, nieco liczniejsza grupa prezentuje postawę pozytywną wobec działalności kół naukowych, druga grupa jest neutralna wobec tego typu działalności studenckiej. Postawy pozytywne prezentują przede wszystkim studenci, którzy są zaangażowani w tę działalność bądź rozważali w swoim życiu studenckim wstąpienie do koła naukowego. Tylko jednostki prezentują postawę negatywną wobec działalności w kołach naukowych.

Moim zdaniem, co też potwierdzają opinie badanych, koła naukowe są potrzebne na uczelniach wyższych. Członkowie tej formy organizacji studenckiej mogą realizować swoje cele, które były też motywami przy podjęciu decyzji o wstąpieniu do koła. Mają okazję do zdobywania i kształtowania nowych kompetencji, do samorealizacji. Mogą rozwijać swoje zainteresowania, poznawać nowych ludzi, pomagać innym czy też w atrakcyjny sposób spędzać wolny czas.

Warto zwrócić uwagę, iż podjęcie decyzji o przyjęciu roli członka koła naukowego u większości studentów było autonomiczne. Niektórzy studenci podejmowali taką decyzję pod wpływem kolegów lub nauczycieli akademickich. 
Wydaje się, iż zaprezentowane wyniki badań dostarczają istotnych informacji dla przewodniczących i opiekunów kół naukowych, szczególnie w kwestii poszukiwania sposobów motywowania studentów do aktywnego w nich uczestnictwa. $\mathrm{Z}$ badań wynika potrzeba rozszerzenia działalności marketingowej, aby zainteresować większe grono młodzieży studiującej tym rodzajem działalności pozaprogramowej w szkole wyższej. Szczególną rolę w tym względzie można przypisać nauczycielom akademickim. Opiekunowie oraz liderzy kół powinni zadbać o bardziej atrakcyjne programy ich działalności.

\section{Bibliografia}

Furmańska M. (2010), Uniwersytet wobec procesu bolońskiej modernizacji, w: A. Karpińska (red.), Edukacja w okresie przemian, Białystok, s. 36.

Soborski W. (1987), Postawy ich badanie i ksztattowanie, Kraków, s. 14-15.

Pilch T. (red. nauk.) (2005), Encyklopedia Pedagogiczna XX I wieku, t. 4, Warszawa, s. 744.

\section{Attitudes of students towards activity in scientific circles}

\section{Summary}

In the article I am presenting attitudes of students towards in scientific circles in the opinion examined chosen randomly, but among them also involved in this activity activities. Empirical material was gathered with the use of the method of the diagnostic survey, the technique of the questionnaire form and the author's tool, of questionnaire form of the questionnaire form for the student.

Keywords: pedagogy, activity, scientific circle, attitude, student. 